\title{
Prosperity, Prophecy and the Covid-19 Pandemic
}

\section{The Healing Economy of African Pentecostalism}

\author{
Asonzeh Ukah \\ University of Cape Town, Cape Town, South Africa \\ asonzeh@yahoo.com
}

\begin{abstract}
One of the intractable problems of Africa is socioeconomic development. It is a "wicked problem" that has defied decades of tinkering and tweaking of economic policies and government interventions. Like many African governments that succeeded oppressive colonial governments, many religious organizations frequently promise their members the help of divine power to deliver development. African Pentecostalism, especially the prosperity variant, has been at the forefront of promising to make its members healthy and wealthy through divine means. How the theology of plenty and healing has practically improved the economic and therapeutic systems of Africa is a question of debate. Some scholars, in line with pentecostal self-representation, claim that Pentecostalism inspires development from below. This essay critiques this self-image of African Pentecostalism in the context of African economic indices and the raging and ravaging coronavirus disease pandemic. The coviD-19 pandemic presents an important challenge but also an opportunity to test the doctrines and claims of pentecostal leaders. In the attempt to cater to leaders' economic self-interest, pentecostal responses to the pandemic have, however, been uncoordinated and have failed adequately to mobilize resources that serve its members and the larger society in their moment of needs.
\end{abstract}

\section{Keywords}

African Pentecostalism - prosperity - poverty - covID-19 - pandemic - faith healing 


\section{Introduction}

This essay is an assessment of contemporary African Pentecostalism and its influence in the re(un)making of social-political and religio-economic life in Africa. ${ }^{1}$ Over the past fifty years, scholars of Africa from different academic disciplines have argued, described, and documented the myriad ways in which pentecostal Christianity has infiltrated or permeated different strata of life and modes of living on the continent. Arguably, Pentecostalism has altered the African spiritual and physical landscape. With ceaseless ritual events held every day of the week that attract large gatherings of worshipers and spiritual seekers, spiritual entrepreneurs have constructed massive worship centers, redirected human traffic toward these sites, and maintained a strong presence and religious economy that have inevitably impacted the flows and ebbs of cities and peri-urban areas. For some scholars, Pentecostal-Charismatic Christianity (PCC) is a revolutionary religion radically transforming Africa and its citizens for the better. The palpable revolutionary impulse in the heart of PCC, the argument goes, is likened to its missionary impulse for the conversion of the world, for telling the Jesus story "from the housetops" (Matt 10:27 ${ }^{2}$ ). The dizzying and wild-fire popularity and expansion of PCC in Africa has been attributed to, among other factors, its claim and capacity to remake and produce a new being and personhood through healing and restoration in all aspects of a believer's life-world. The promise of being "born again" through supernatural power is a strong, empowering incentive to many people. As it claims to heal society of brokenness and poverty through its prosperity theology and economic ideologies, so it also claims to bring healing to individuals afflicted by ill health and diseases through its deliverance and healing doctrines and practices.

Generally, bodily or physiological healing through faith or religious rituals is an entrenched medical and therapeutic system in African indigenous religions. ${ }^{3}$ The place and influence of Pentecostalism in Africa is brought into

1 I am grateful for the comments and suggestions from the two anonymous reviewers and the editors of Pneuma. Also, I am grateful to Banchileyew Silewondim Getahun for assistance during the revision and editing of this paper. The usual caveats hold. Research for this essay was partly supported by the National Research Foundation of South Africa (Reference number [UID] 85397). The opinions, findings and conclusions or recommendations expressed are those of the author; the NRF accepts no liability whatsoever in this regard.

2 All Bible citations, except otherwise specified, are from The New Jerusalem Bible standard edition (London: Darton, Longman \& Todd Ltd., 1985).

3 Joel Cabrita, The People's Zion: Southern Africa, The United States and A Transatlantic FaithHealing Movement (London: Belknap Press, 2018), 5-8; Asonzeh Ukah, "Religion in Pre- 
sharper relief in the context of the unfolding coronavirus pandemic and the COVID-19 (also known as SARS-CoV-2) ${ }^{4}$ disease that it causes. In CoviD-19 Africa, unprecedented and previously unimaginable rules of closures are the norm and experience of millions of Africans. The appeal of Pentecostalism in Africa has been argued to be its emphasis on the power of the Holy Spirit to control and direct believers' lives and bring forth its power and fruits, such as healing, prophecy, speaking in tongues, and spiritual empowerment to turn a believer into a new, empowered person. Pentecostal leaders have made a great deal of capital by claiming to have the power to produce wealth and prosperity, healing, and prognostication. Such leaders, who have transformed themselves into spiritual entrepreneurs and owners of transnational franchises of global fame, are more powerful, wealthier, and more popular than inventors and politicians or even businesspersons. ${ }^{5}$ Under the covid-19 pandemic, however, social life and its structures have been disrupted in ways never thought possible or imagined. Collective face-to-face ritual performances and mechanisms not only build, maintain, and sustain social dynamics and solidarity; they are also the foundations of religion, social systems, and community domains. Apart from, or in addition to, depriving people of the rituals of solidarity and its high mortality rate, CoviD-19 clinically targets social bonds and all that people need in the building and maintenance of social systems. How have Africans and Africa fared in the context of Pentecostalism and the unfolding demographic catastrophe in the wake of the CoviD-19 pandemic? Every religious tradition and community faces opportunities and challenges thrown up by the pandemic; perhaps, however, those groups that emphasize wealth, healing, and health may be more in the spotlight because these are exactly what the disease disrupts with reckless abandon. A recent study by the African Development Bank concludes that "the pandemic will slow Africa's economic growth and exacerbate extreme poverty ... In particular the continent could record an increase in the rate of extreme poverty by $2.14 \%$ or $2.84 \%$ under the baseline or worse-case-scenarios, respectively, which translates to an additional

Contact Africa," in V. Garrard-Burnet, P. Feston, and S.C. Dove, eds., The Cambridge History of Religions in Latin America (Cambridge: Cambridge University Press, 2016), 47-61.

4 SARs-CoV2 means "Severe acute respiratory syndrome coronavirus 2"; the disease it causes is "Coronavirus Disease (20)19," for short, COVID-19. The "CO" stands for corona; the "VI" for virus; the "D" for disease and the "-19" for 2019; https://www.who.int/emergencies/diseases /novel-coronavirus-2019/technical-guidance/naming-the-coronavirus-disease-(covid-2019) -and-the-virus-that-causes-it.

5 Asonzeh Ukah, "Sacred Surplus and Pentecostal Too-Muchness: The Salvation Economy in African Megachurches," in Stephen Hunt, ed., Handbook of Megachurches (Leiden: Brill, 2020), 323-344. 
28.2 million or 37.5 million people sliding into extreme poverty." ${ }^{6}$ It is important, therefore, to examine through critical lenses how PCC has transformed and healed Africa and its citizens more than fifty years after a large swath of Africans embraced the religion, as well as to examine its interpretation and responses to the CoviD-19 pandemic. The argument is not whether Christianity or the Jewish and Christian Scriptures have economic relevance: they do speak about money, wealth, hired labor, investment, indebtedness, and profit. ${ }^{7}$ The issue is to what extent African Pentecostalism has influenced the radical social transformation of Africa in the twenty-first century.

This article is divided into five sections: The first section examines the prosperity claims of the PCC against the socioeconomic indices of contemporary sub-Saharan Africa. The second section discusses the pentecostal paradoxes whereby growth and increased individualization have failed to produce social reform and transformation in Africa. The third section argues that, conceivably, Pentecostalism is a religion most suited for a pandemic such as coviD-19 because historically Christianity has had a long history of preparing and acting within the context of epidemics and pandemics. The fourth section looks at some of the interpretations and explanations offered by prominent pentecostal leaders and their organizations for the covid-19 pandemic and how such responses shine some light on the meaning and influence of African Pentecostalism in the twenty-first century. The fifth section concludes the article by urging for a reassessment of Pentecostalism's power vis-à-vis the realities of the postcolonial African state.

No continent has so rapidly changed its religious, economic, and political landscapes as Africa. In the last 150 years, Africa, especially the sub-Saharan section, ${ }^{8}$ became christianized through a variety of factors, such as European mis-

6 H. Morsy, L. Balma, and A.N. Mukasa, "Not a Good Time: Economic Impact of covid-19 in Africa," Working Paper Series No. 338, African Development Bank, Abidjan, Côte d' Ivore (2020), 24 .

7 Nimi Wariboko, God and Money: A Theology of Money in a Globalizing World (Lanham: Lexington Books, 2008); Devin Singh, Divine Currency: The Theological Power of Money in the West (Stanford: Stanford University Press, 2018).

8 Sub-Saharan Africa, with a population of about 1.09 billion people, is one of the most intensely religious parts of the world, where nine in ten persons claim to be very religious, according to Pew Research Center, The Future of World Religions: Population Growth Projections, 2010-2050 (2015), 163 . 
sionary activities in the aftermath of the transatlantic slave trade, the work of returnee ex-slaves who actively promoted Christian evangelical programs and propaganda, and the aggressive and brutal European colonization that, in many instances, worked in tandem with missionary agendas. Western Christian missionaries in sub-Saharan Africa often aligned their program of civilizing the natives with "commerce, conquest, and colonization."9 The cumulative outcome of these efforts has shown that no continent has been christianized in so short a time as Africa. The corollary is that no continent has abandoned, at least superficially, its cultures and traditions as fast and eagerly as Africans. Furthermore, of all forms of social transformation occurring in Africa, religious change has been the most profound and far-reaching. Because of historical factors evident in the way the continent became missionized, African Christianity, more appropriately christianities, is plural and variegated. Coptic and Orthodox Christianity predominates in North Africa, from Egypt through to Eritrea, Ethiopia, and the Sudan. Catholic, Protestant, and African Initiated christianities dominate from South Sudan to Zimbabwe and South Africa. Further, in this part of Africa, Euro-American missionaries transposed and remapped all their medieval denominational quarrels, divisions, and hate onto the African landscape. ${ }^{10}$ Within Protestant Christianity, the Pentecostal-Charismatic Churches (PCCs), are arguably the most socially visible and perhaps the subset that has most captured both public and scholarly imagination since the 1970s. The PCC s are internally diverse in terms of organization, theologies, liturgies, practices, and leadership styles. While many of them are characterized by the emphasis on the power of the Holy Spirit to transform the believer, they differ considerably on leadership and attitude toward the world as well as the place and power of the Bible in the life of the believer.

Through intimate engagement with modern media, neoliberal commercial practices, and transnational travel, African Pentecostalism has achieved social

9 David Chidester, Christianity: A Global History (New York: HarperCollins, 200o), 412.

10 In many parts of sub-Saharan Africa, Catholic converts would not send their children to Anglican-founded and managed schools and vice versa. The children of non-converts were forcibly baptized and converted and given "Christian names" if their parents wished them to attend mission schools. Even as the new Christian faith created new denominational communities, it divided and polarized traditional African society along the lines of Euro-Western historical religious conflicts. European expeditionary rivalry, the transatlantic slave trade, the Berlin conference of 1884-1885, the Edinburgh Conference of 1910, and Western racism and Eurocentrism all combined to influence the course and color of colonial Christianity in Africa and its modes of appropriation by Africans. See Ogbu Kalu, "West African Christianity: Padres, Pastors, Prophets, and Pentecostals," in Charles E. Farhadin, ed., Introducing World Christianity (Sussex: Wiley-Blackwell, 2012), 36-50. 
and economic visibility that other older forms of Christianity are still struggling to attain. The most media-savvy group within African Pentecostalism emphasizes what has been called the prosperity gospel, a doctrinal and theological orientation that claims that a true belief is authenticated and validated by wealth and health as the legal rights of the believer. Leaders of prosperity Pentecostalism claim to have the power to heal different kinds of diseases and illness. They also promise to make those who patronize them and give generously in support of their ministries rich and stupendously wealthy. This subset of African Pentecostalism has attracted the largest crowds in a very short time. Doubtlessly, therefore, the claim to the power to perform miracles of healing and wonderment as well as the production of wealth and riches has been central to the legitimation of PCC leaders and their organizations. This claim to produce healing and wealth has been adduced as Pentecostalism's power to transform society and produce development, that is, a qualitative improvement at both individual and societal levels. For many African pentecostal leaders, development is quantified in material terms as the goods of modernity: schools, cars, housing, banks, financial institutions, and healthcare facilities. Ordinarily, as a concept originally derived from biology and popularized by colonial and Western and modernist rhetoric about civilization, development signifies progress, a positive social change that includes physical, environmental, and socioeconomic and demographic elements indicating increased human and social capabilities to improve and innovate in response to the human condition or challenges. African Pentecostalism's embrace of material acquisition and accumulation of physical assets indicates its acceptance of an economistic and materialistic meaning of "development," which undermines the rhetoric of "development from below."11 To what extent has Pentecostalism positively transformed the African social landscape or produced common goods that are, in principle, accessible to anyone and everyone irrespective of belief and belonging?

Indeed, if Pentecostalism is transformative of any society, it would be most evident in Nigeria, which is characterized as the pentecostal capital of the world. Pentecostal Christianity is arguably the second most popular export of the country (after oil). Apart from Nigeria, pentecostal Christianity is popu-

11 Babatunde A. Adedibu, "Approaches to Transformation Development: The Case of the Redeemed Christian Church of God, Nigeria," in Philipp Öhlmann, Wilhelm Gräb, and Marie-Luise Frost, eds., African Initiated Christianity and the Decolonisation of Development: Sustainable Development in Pentecostal and Independent Churches (London: Routledge 2019), 141. 
lar across sub-Saharan African countries such as Ghana, Côte d'Ivoire, ${ }^{12}$ Zambia, Zimbabwe, and South Africa. In these countries, the relationship between religion or divine action and economic well-being is a staple offering of prosperity Pentecostalism. ${ }^{13}$ The scholarly and practitioners' argument has been consistent: the PCC s have "had a radical and public impact on African cities, believers and politics" by creating ruptures in religious authority, aesthetics, introducing new language and a new system of public morality all of which positively transforms Africa and Africans. ${ }^{14}$ There is a rupture between pentecostal claims and promises of creating or generating and distributing wealth and economic well-being (not just among believers but across society) and the indices of socioeconomic life in (sub-)Africa. The example of Nigeria before the onset of the coronavirus pandemic would be instructive in illustrating this rupture between promise and reality. Understanding this rupture would provide further insight into the state and performance of Pentecostal-Charismatic Christianity in Africa in the twenty-first century.

Nigeria in the twenty-first century is "the poverty capital of the world," overtaking "India as the country with the most people living in extreme poverty." 15 With a population of about 206.13 million people in $2020,{ }^{16}$ more than 87 million of these live in extreme poverty. In 2016, Nigeria's own National Bureau of Statistics painted a gloomier picture of 112 million people in the country living below the poverty line. ${ }^{17}$ Yet, despite this situation, or rather because of it, prosperity Pentecostalism booms and flourishes and promises to be the answer to all problems. Nigeria is home to the largest physical structures dedicated to the production, circulation, and consumption of religion; the largest pentecostal real estate is to be found in the country. Of the ten wealthiest pen-

12 Konstanze N'Guessa, "Côte d'Ivoire: Pentecostalism, Politics and Performances of the Past," Nova Religio: The Journal of Alternative and Emergent Religions 18, no. 3 (2015): 80100.

13 J. Kwabena Asamoah-Gyadu, "Spirit/Religion and Ethics in African Economies," in Nimi Wariboko and Toyin Falola, eds., The Palgrave Handbook of African Social Ethics (London: Palgrave Macmillan, 2020), 308.

14 Ilana van Wyk, "Crooked Prophets, Ungodly Politicians and their Publics: Popular Christian Engagements in South Africa," PentecoStudies 19, no. 1 (2020): 36-61, at 36.

15 "Nigeria, the Poverty Capital of the World," https://endpoverty.org/2019/10/11/nigeria-pove rty-capital-of-the-world/ (accessed December 8, 2019).

16 https://worldpopulationreview.com/countries/nigeria-population/ (accessed July 1, 2020).

17 Eniola Akinkuoto, "With $87 \mathrm{~m}$ Poor Citizens, Nigeria Overtakes India as World's Poverty Capital," Punch (Lagos), June 26, 2018, https://punchng.com/with-87m-poor-citizens-niger ia-overtakes-india-as-worlds-poverty-capital/ (accessed December 8, 2019). 
tecostal entrepreneurs in Africa, seven are Nigerians. The Nigerian situation can be extrapolated to different parts of sub-Saharan Africa where pentecostal activism and cycles of rituals thrive. Because of the physical expansion of worship spaces and the strong media presence of pentecostal entrepreneurs who maintain the activities and practices on YouTube, Facebook, Twitter, Instagram, and other social media, Pentecostalism is alleged to be the fastest expanding religion on the continent. ${ }^{18}$ Strong and pervasive media use by pastors who claim exceptional supernatural power to bring about change in the lives and circumstances of believers reinforces this impression. These pastors are known to promise the public immeasurable physical and fiscal, material, and meta-social wealth and wellness in exchange for faithful tithing and financial support for the pastors' ministries. Pentecostal presence is felt in many different areas of social life, including primary, secondary, and higher education, banking and finance, the media industry, and politics. Some scholars vigorously assert that Pentecostalism is a movement of positive social transformation without which "the whole continent [of Africa] would be worse off."19 Sociologist Ebenezer Obadare claims that since 1999 Nigeria has slowly transformed into a "pentecostal Republic" on account of the visible presence of pentecostal actors in electoral and partisan politics. ${ }^{20}$

With a population of 1.34 billion people,$^{21}$ nearly half of whom are Christians, "[t]oday, Christianity in Africa is increasingly important in the world stage. The prognoses show that by the year 2020 Africa will be the most Christian continent in the Global South and that by 2050 most Christians in the entire world will live in Africa." ${ }^{22}$ Christians in Africa are concentrated in the sub-Saharan region of the continent, where they constitute more than 54 percent of a total population of more than $75^{\circ}$ million, thus identifying Africa as having "the largest Christian population in the world." ${ }^{23}$ The population of Pentecostal-Charismatic Christians in sub-Saharan Africa is estimated at

18 Gabriel Faimau and William O. Lesitaokana, eds., New Media and the Mediatization of Religion: An African Perspective (Newcastle upon Tyne: Cambridge Scholar Publishing, 2018).

19 Wanjiru M. Gitua, Megachurch Christianity Reconsidered:Millennials and Social Change in African Perspective (Downers Grove, IL: IVP Academic, 2018), 37.

$20 \quad$ Ebenezer Obadare, Pentecostal Republic: Religion and the Struggle for State Power in Nigeria (London: Zed Books, 2018).

21 https://worldpopulationreview.com/continents (accessed July 1, 2020).

22 Louise Müller, "Christians in Africa," in George D. Chryssides and Stephen E, Greggs, eds., The Bloomsbury Handbook to Studying Christians (New York: Bloomsbury Academic, 2020), 151 .

23 https://www.persecution.org/2019/04/25/african-christian-population-largest-world/. 
115 million. ${ }^{24}$ Religio-demographic change in Africa has been swift, deep, and widespread. "Religion has been a powerful force in defining the varied cultures and civilization of Africa, and in turn, the larger world."25 The numeric success of Christianity in Africa has resulted in some scholars (mis)recognizing and (mis)characterizing such a massive shift in religious allegiance as a "revolution." ${ }^{26}$ However, exactly how revolutionary African Pentecostalism is has not been adequately articulated, explained, or even supported with empirical evidence.

Some construe the large numbers of Christians in Africa as producing longterm positive socioeconomic change. However, it is not clear to what extent this radical and profound socio-religious transformation portends the material well-being of the continent and its diverse peoples. Historically, Christianity is older in Africa, where it has remained as a unique tradition shaped by its context, ${ }^{27}$ than in Europe, although its social, economic, and political consequences remain ambiguous, even contradictory. Yet, the problem with the claims of macro transformative powers of Pentecostalism is that they are high on optimism, romanticizing the African situation, and low on reality, as they do not fit with the quotidian experience of Africans. For example, amid pentecostal promised economic abundance and well-being, each year a record number of young Africans are either enslaved in North Africa (especially in Libya!) or perish crossing the deserts of North Africa or the Mediterranean Sea in search of a better life in Europe. ${ }^{28}$ More Africans are owning property in

24 Douglas Jacobsen, The World's Christians: Who They Are, Where They Are, and How They Got There (West Sussex: Wiley-Blackwell, 2011), 156.

25 Douglas Thomas and Temilola Alanamu, eds., African Religions: Beliefs and Practices through History (Santa Barbara: ABC-CLIO, 2019), xvii.

26 Musa A.B. Gaiya, The Pentecostal Revolution in Nigeria, Occasional Paper, Centre of African Studies, University of Copenhagen, 2002; Richard Burgess, The Civil War Revival and Its Pentecostal Progeny (1967-2006), Cumbria: Regnum Studies in Mission, 20o8; Ruth Marshall, Political Spiritualities: The Pentecostal Revolution in Nigeria (Chicago: University of Chicago Press, 2009).

27 David E. Wilhite, Ancient African Christianity (London: Routledge 2017), 1-2. Archaeological evidence from Aksum (modern Ethiopia) demonstrates conclusively that the town was a trade and religious center and "the centre of political power in sub-Saharan Africa's earliest (Pre-Aksumite) complex polity" and the oldest known Christian church constructed in the fourth century of the Common Era (Michael J. Harrower et al., "Beta Samati: Discovery and Excavation of an Aksumite Town," Antiquity 93, no. 372 [2019]: 1534-1552 at 1535).

28 Robert Press, "Dangerous Crossings: Voices from the African Migration to Italy/Europe," Africa Today 64, no. 1 (2017): 3-27; Paolo Campana, "Out of Africa: The Organisation of Migrant Smuggling across the Mediterranean," European Journal of Criminology 15, no. 4 (2018): 481-502; Roza E. Patterson, "Black Bodies Drowning in the Mediterranean Sea: Why 
Western countries and the Middle East; also, more Africans, including many pentecostal leaders, own private aircraft. Yet, we are witnessing more Africans ingesting disinfectants or being sprayed with insecticides or eating rodents and snakes as a manifestation of divine power to heal diseases and produce wealth. ${ }^{29}$ What sociological insights help us make sense of these contradictory data sets and experiences of Africans and Africa in the twenty-first century? How are the pentecostal claims to heal and make rich meaningful and realistic when large numbers of Africans face food insecurity? ${ }^{30}$

Using the methodology of legal-economic analysis, ${ }^{31}$ Geoffrey P. Miller examines how certain sources in the Hebrew Bible were deliberately framed as a "legitimating ideology" by the priestly class to institutionalize ritual "entitlements, obligations and proper performance of the ritual" to the benefit of the priestly class. ${ }^{32}$ Similarly, prosperity Pentecostalism in its teaching and practices, at least to a significant extent, serve the economic interests of pastors and the leadership rather than the laity or the larger society. Defying the empirical and historical evidence about how Europe was transformed, J. Kwabena Asamoah-Gyadu argues that “[ $\mathrm{t}]$ he principles set out in Max Weber's Protestant

Does the World Not Care?," UCLAJournal of International Law and Foreign Affairs 23 (2019): 183-219.

29 Asonzeh Ukah, "The Deregulation of Piety in the Context of Neoliberal Globalisation: African Pentecostalisms in the 21st Century," in Vinson Synan, J. Kwabena AsamoahGyadu, and Amos Yong, eds., Global Renewal Christianity: Spirit-Empowered Movements Past, Present, and Future, vol. 3: Africa (Lake Mary, FL.: Charisma House Publishers, 2016), 362-378; Kelebogile T. Resane, “'And They Shall Make You Eat Grass like Oxen' (Daniel 4:24): Reflections on Recent Practices in Some New Charismatic Churches," Pharos Journal of Theology 98 (2017): 1-17; Mookgo S. Kgatle, "The Unusual Practices within Some Neo-Pentecostal Churches in South Africa: Reflections and Recommendations," HTs Teologies Studies/Theological Studies 73, no. 3: 1-8; Nkanyiso Kingdom Maphumulo, "Imago Dei and Faith-Healing Practices in the Newer Pentecostal-Charismatic Churches (NPCCs) in South Africa: A Human Dignity Perspective," Masters Diss., School of Theology, University of KwaZulu Natal, 2019 .

30 Tom Burgis, in The Looting Machine: Warlords, Oligarchs, Corporations, Smugglers, and the Theft of Africa's Wealth (New York: Public Affairs, 2015) details some of the ways in which Africa's wealth is frittered away out of the continent. The sources of Africa's poverty are multilayered and deeply entrenched such that no religious doctrine or ritual is able to lift it away suddenly and permanently.

31 Legal-economic analysis, according to Geoffrey P. Miller, "provides a methodology for understanding the nature and function of social institutions in terms of the behavioral incentives that these institutions create for individuals in the society, including, importantly, individuals whose economic welfare depends on the functioning of the institutions themselves," Geoffrey P. Miller, "Ritual and Regulations: A Legal-Economic Interpretation of Selected Biblical Texts," Journal of Legal Studies 22 (June 1993): 477-501, at 478. 
Ethic Thesis and its promotion of thrift and Christian capitalism had been very much a part of Western mission Christian spirituality that evangelized most of Africa," ${ }^{33}$ as if "Christian" Europe developed, created its wealth, and evolved socioeconomically through the practice of the Calvinist puritan ethic of hard work and thrift. No society has developed in socioeconomic and material terms by producing, circulating, and consuming religion or developing metaphysical ideas. The popular "Protestant Ethic" hypothesis of the German sociologist Maximillian Karl Emil Weber (1864-1920), which postulates that the West developed by imbibing and cultivating the incipient "spirit of capitalism" as espoused by a pious Calvinist sect, was directed toward two primary objectives, none of which was to show that Calvinist spirituality or practice was a causal factor in the economic development of the West. ${ }^{34}$ The first objective was to prove that rationalization of thought and practice was a primary Western achievement or attribute; the second was to confront the brutal attacks of Karl Marx on western Christianity by showing that Christianity was positively functional rather than dysfunctional in its societal impacts. ${ }^{35}$ As more recent scientific scholarship has shown, the prosperity of Europe (and North America), contrary to the hypothesis that it was a byproduct of Calvinist religion, is (largely) traced to the plunder of the Americas by arriving Europeans in the fifteenth century who killed more than 59 million of the original owners of the land over a hundred years, causing a dramatic environmental shock by so doing. ${ }^{36}$ What these early Europeans did in the Americas, their compatriots did almost everywhere else they went through the slave trade, extreme extraction, and colonialism. ${ }^{37}$ Understanding the role of the enslavement of

33 J. Kwabena Asamoah-Gyadu, "Spirit/Religion and Ethics in African Economies," 306.

34 Max Weber, The Protestant Ethic and the Spirit of Capitalism ([1920] trans. with new intro. Stephen Kalberg) (New York: Routledge, 2002). While Weber indicated that his thesis was a "historical case" rather than a contemporary analysis of social transformation, many of those who appeal to this hypothesis, such as Asamoah-Gyadu, try to use it to explain contemporary social and structural change (13, emphasis in the original).

35 See Karl Löwith, Max Weber and KarlMarx, 2nd ed., edited with new intro. Tom Bottomore and William Outhwaite, (London: Routledge, 1993), 121-125.

36 A. Koch, C. Brierley, M.M. Maslin, and S.L. Lewis, "Earth System Impacts of the European Arrival and Great Dying in the Americas after 1492," Quaternary Science Reviews 207 (2019): 13-36.

37 Daron Acemoglu and James A. Robinson, Why Nations Fail: The Origins of Power, Prosperity, and Poverty (London: Profile Books), 88-9o. According to the authors, "religion, national ethics, African or Latin values - are just not important for understanding how we got here and why the inequalities in the world persist. Other aspects [of culture], such as the extent to which people trust each other or are able to incorporate, are important but they are mostly an outcome of institutions, not an independent cause," 57 . 
Africans and how that pernicious trade facilitated the development of Western financial institutions, rather than the role of pious Calvinists, is important in understanding the creation of European wealth and the evolution of capitalism. Attributing the prosperity of Europe, the United States, and Canada to a religious ethic or the rationalization of thought or secularization of religious worldview of Calvinist puritans is a clear sign of Weber's romantic idea of religion. ${ }^{38}$ Partly from this bias for religion, the notion that religion is good for society has been propagated to many parts of the world. This idea functions partly to conceal the historical fact that many Western countries, such as the United States of America, were founded on genocide and plunder perpetrated by European Protestation Christians rather than by adhering to a biblical ethic or Christian morality and work ethos. The notion of the positive value of, and bias for, religion, especially Christianity, is especially evident in Africa but functions to secure and institutionalize the economic interests of the clergy as well as managers of postcolonial Africa's weak political institutions.

There are two broad senses in which "the pentecostal revolution" referred to earlier is being used by scholars. The first is that the pentecostal-charismatic movement has created a new spiritual or pneumatic consciousness among its followers, especially in their relationship with God. The second sense is the description of how Pentecostalism has generated socioeconomic development, social trust, and institutions in parts of Africa where churches and religious nongovernmental organizations claim to operate social infrastructures such as schools, orphanages, hospitals, and vocation centers. Realistically, what may count as revolutionary may be the sheer number of its adherents (about 10 percent of the total Christian population of nearly 631 million); its social visibility and effervescence are certainly not in doubt. However, sustained societywide change brought about by pentecostal beliefs and practices in Africa is unproven, unsupported by the empirical facts of increasing inequality and the concentration of wealth in the hands of a small class of religious entrepreneurs and their political adherents. In this sense, the claimed positive correlation between Pentecostalism and socioeconomic development or the healing of economic inequality is a myth or a future objective. ${ }^{39}$ Considering the objective

38 Martin Riesebrodt, The Promise of Salvation: A Theory of Religion, trans. Steven Rendall (Chicago: University of Chicago Press, 2010), 67; Biko Agozino, "The Africana Paradigm in Capital: The Debts of Karl Marx to People of African Descent," Review of African Political Economy 41, no. 140 (2014): 172-184.

39 According to St. Paul "The time is sure to come when people will not accept sound teaching, but their ear will be itching for anything new and they will collect themselves a whole series of teachers according to their own tastes; and then they will shut their ears to the 
realities of contemporary Africa, the purported revolutionary power, impetus, or impulse of Pentecostalism in Africa seems to present a paradox: ${ }^{40}$ the doctrinal and strident emphasis on prosperity and wealth has grown in an inverse relationship to Africa's socioeconomic development and well-being.

\section{The Pentecostal Paradox}

The import of African Pentecostalism means that the pentecostal paradox, the empirical facts of expansion in the context of continued economic downturn and challenges, and the continued growth of the entrepreneurial subset, demands some explanation. The first indubitable experience is that about one in five Africans is undernourished, according to a recent United Nations report. ${ }^{41}$ While rich in mineral wealth, Africa is the most impoverished part of the world in the twenty-first century; it is home to twenty-three out of twentyfive of the poorest economies in the world, and many of these economies are in sub-Saharan Africa, where Pentecostalism attracts its most ardent and numerous followers. ${ }^{42}$ The largest pentecostal ritual gatherings in the world are held in sub-Saharan Africa; regular weekly or monthly religious events attract several thousands of believers for six to seventy-two hours. ${ }^{43}$ African pentecostal churches invest extensively in acquiring land and property and

truth and will turn to myths" (2 Tim 4:3-4). "Myth" is used in its original Greek meaning as "sacred narratives," that is, stories, visions, and expectations that imaginatively supply explanations for human experience(s). See David Chidester, Patterns of Transcendence: Religion, Death and Dying, 2nd ed. (Belmont: Wadsworth, 2002), 18.

40 Contemporary modern society is marked by high levels of paradoxes, especially regarding the individual and individual self-realization as the hallmark of "institutionalized expectations inherent in social reproduction" of values "where the processes which once promised an increase of qualitative freedom are henceforth altered into an ideology of de-institutionalization, ... of inner emptiness, of feeling oneself to be superfluous, and of absence of purpose," Axel Honneth, "Organized Self-Realization: Some Paradoxes of Individualization," European Journal of Social Theory 7 , no. 4 (2004): 463-478, at 463; also Dick Houtman, Stef Aupers and Willam de Koster, Paradoxes of Individualization: Social Control and Social Conflict in Contemporary Modernity (London: Routledge, 2011).

41 FAO, IFAD, UNICE F, WFP and WHO, The State of Food Security and Nutrition in the World 2019: Safeguarding against Economic Slowdowns and Downturns (Rome, 2019).

42 "The Poorest Countries in the World," https://www.worldatlas.com/articles/the-poorest -countries-in-the-world.html (accessed August 10, 2019).

43 J.D.Y. Peel, Religious Encounter and the Making of the Yoruba (Bloomington: Indiana University Press, 2003), 314; Asonzeh Ukah, "Expansion," in Michael Stausberg and Steve Engler, eds., Oxford Handbook for the Study of Religion (London: Oxford University Press, 2016), 676-678. 
constructing massive pentecostal cities, prayer camps, arenas, auditoria, and real estate. All these coexist with a large number of Africans needing humanitarian food assistance. According to a United Nations report, of the 113 million people in fifty-three countries of the world who "suffered acute hunger" caused by "food insecurity," "more than half-65.5 million people-were in Africa" in $2019 .^{44}$

In sub-Saharan Africa, combinations of conflict, floods, droughts and other natural hazards led to new internal displacements to double in just three years (2015-2018). Some of the poorest and most vulnerable are trapped in a vicious cycle, unable to leave high-risk areas or facing new risks as they move to urban areas that lack adequate housing, infrastructure and services. In 2018, 6 of the 10 largest flooding events that triggered displacement were in sub-Saharan Africa, and urban areas were the worst hit. ${ }^{45}$

This graphic situation, which is now exacerbated by economic fallouts of the COVID-19 pandemic as detailed by the African Development Bank report cited in the introduction, ${ }^{46}$ presents a glaring opportunity for a coordinated pentecostal social intervention and action across Africa. However, the reality is different; arguably, no pentecostal organization is involved in commercial food production and distribution. They are more visible in the financial and moneyed sector, such as banking, insurance, real estate, and mortgage finance. The stark hunger situation presented by the UN report above is put into sharp relief if contrasted with another fact: the wealthiest pentecostal pastors are also found in Africa (an indication that the pentecostal wealth of the few-like capitalism itself-requires the poverty of the many!). According to one account based on Forbes's 2019 calculations, of the twenty richest pentecostal pastors in the world, ten are Africans (seven Nigerians, two South Africans, and one Zimbabwean).${ }^{47}$ Perhaps, if a fraction of the lands dedicated to pentecostal rit-

44 United Nations Office for the Coordination of Humanitarian Affairs (OCHA), Global Humanitarian Overview 2020 (Geneva: OCHA, 2019), 12.

45 оснA, Global Humanitarian Overview, 17. On the impact of adverse climate change on the economic fortunes of African countries, see African Development Bank, Climate Change Impact on Africa's Economic Growth (2019), https://www.afdb.org/en/documents/climate -change-impacts-africas-economic-growth (accessed July 9, 2020).

46 Morsy, Balma, and Mukasa, "Not a Good Time: Economic Impact of covid-19 in Africa," $1-32$.

47 https://www.oasdom.com/richest-pastor-in-the-world-forbes/ (accessed August 10, 2019). The Nigerians are David Oyedepo, Chris Oyakhilome, T.B. Joshua, Ayo Oritsejafor, 
uals and ceremonies as well as half of the time dedicated to pentecostal rituals and services were channeled toward the cultivation of agricultural produce, the number of those suffering from hunger, poverty, and starvation would very likely also be reduced.

Understanding the pentecostal paradox means that the context of the founding of many of the large pentecostal organizations informs their attitude, theology, and practice toward the larger society. These organizations were founded or transformed under the economic crisis of the 1970s and 1980s caused by "the abuse of political power"48 and downsizing of the economy and subsequent neoliberal ethos imposed by the Bretton Woods institutions. ${ }^{49}$ The pentecostal healing economy emerged from the crucible and turmoil of shrinking postcolonial African states' ability to meet their political responsibilities in delivering goods to their citizenry. Under the structural adjustment programme imposed by the World Bank and the International Monetary Fund, religious entrepreneurs emerged commingling indigenous spiritual quests, and desires with neoliberal logic and domination defined and disseminated by the corporate and media world of the time. More important, and consistent with the zeitgeist, it is one that is dominated by material objects that can be consumed, possessed, or exorcised (when these are evil and depersonalizing). This neoliberal turn is described as a mode of thought and practice whereby calculation, competition, lack of state of oversight or regulation, the profit motive, and the sovereignty of the market reign supreme over any other considerations. In a paper published by experts at the World Bank, neoliberalism is described as a market agenda that rests on two principal pillars of "increased competition-achieved through deregulation" and "a smaller role for the state, achieved through privatization and the limits on the ability of government" to intervene in fiscal deficits and accumulated debts. ${ }^{50}$

While the concept of neoliberalism emerged in the early 1930s, the trend toward its widespread adoption by states and organizations or corporations was noticeable in the 198 os when Western governments urged, cajoled, blackmailed, and even threatened frail African postcolonial states to adopt poli-

Matthew Ashimolowo, and Kris Okotie. The two South Africans are Tshifinwa Irene and Ray Macaulay; the lone Zimbabwean is Uebert Angel.

48 Elias K. Bongmba, The Dialectic of Transformation in Africa (New York: Palgrave Macmillan, 2006), 63.

49 Sunday Olaoluwa Dada, "The Bretton Woods Institutions and Economic Development in Africa," in N. Wariboko and T. Falola, eds. The Palgrave Handbook of African Social Ethics (London: Palgrave Macmillan, 2020), 339-369.

$5^{\circ} \quad$ Jonathan D. Ostry, Prakash Lougani, and Davide Furceri, "Neoliberalism: Oversold?," Finance \& Development 53, no. 2 (June 2016): 38-41. 
cies of privatization and structural (re-)adjustment, downsizing of state structures and social infrastructures. The International Monetary Fund and World Bank designed, recommended, and sponsored structural adjustment programs (SAPs) that were foisted on these states (including Liberia, Nigeria, Angola, Zambia, Ghana, and Kenya) with devastating outcomes. Not one of these countries improved or transformed positively in terms of socioeconomic indices of development after implementing SAPs. As hindsight has shown now, even South Africa, which followed the recommendations of the World Bank after the 1994 transition from apartheid to neo-apartheid rule, has witnessed that its economy did not improve and develop as the ANC leaders were promised, due to entrenched Western interest and exploitation that undergirded and drove such policy recommendations. The conditionalities attached to the lending facilities provided by these financial institutions worsened the economic situations of African states, unsurprisingly making them more acute and allencompassing. Some of the recommendations of the international financial institutions directed African states to shrink and privatize higher education and healthcare, because these were construed as private goods, and some states followed them. ${ }^{51}$ The outcome of these policies for African societies and citizens was a near-apocalyptic social meltdown, the consequences, and reverberations of which are still being felt in many African states. No country that devalued its currency had improved from implementing this measure, but this was also one of the staples of structural adjustment. This context was the ideological background within and against which African Pentecostalism emerged, appropriating the conditions of its emergence to define and refine its self-making, self-(re)presentation as a neoliberal or entrepreneurial religion. As structural adjustment did not produce wealth and prosperity for Africa and Africans in the late twentieth century, so also Pentecostalism-following its corporatist ideology and the enthronement of individualism and profitseeking - is not producing wealth or economic healing for its followers and the larger African society in the twenty-first century. If economic healing has not worked out according to pentecostal rhetoric and practices in Africa, ${ }^{52}$ many agree that the claim for physiological healing and deliverance from spiritual evil has produced strong traction and appeal for the pentecostal movement in

$5^{1} \quad$ Mahmood Mamdani, "The African University, London Review of Books 40, no. 14 (July 19, 2018).

52 This conclusion reflects the complex relationship between religion (generally) and the political economy development and the multilevel ambivalences that Sabine Dreher amply demonstrates in her book Religions and International Political Economy (London: Palgrave Macmillan, 2020). 
Africa. The need for healing and physiological wellness, safety, and wellbeing is more acutely experienced during periods of mass sickness and epidemics such as the ongoing novel coronavirus disease (COVID-19) pandemic.

\section{In the Eye of the Covid-19 Pandemic Storm}

The storm is upon us ... The coronavirus storm is far fiercer and more destructive than any we have known before.

President Cyril RAmaphosa, National Address on the Efforts to Contain the COVID-19 Pandemic, Union Buildings, Tshwane, July 12, $2020^{53}$

Many African pentecostal pastors and their mega-organizations make strong claims to provide bodily healing as their special or unique selling point. After prosperity, healing and deliverance are the next most important sacred goods on sale in the African pentecostal marketplace. Through healing and deliverance services, these churches "aspire, even claim, to reconstruct religion as a technology that responds to the daily needs and experiences of spiritual and physical insecurity which many Africans confront on a daily basis. ${ }^{\prime 4}$ The way African pentecostal establishments respond to the CoviD-19 pandemic will be an indication of its impact on the continent and the lives of its followers for a long time to come. At no time has religion been mobilized as a resource for the control of risks, illness, disease, environmental crisis, and de-development in Africa as the way it is at the present moment. In the wake of unfolding the novel coronavirus pandemic, many people across the world are experiencing the devastation to life, social trust, ${ }^{55}$ the economy, and the healthcare system. On January 30, 2020, the World Health Organization declared the CoviD-19 outbreak a Public Health Emergency of International Concern (PHEIC). On March 11, 2020, the organization declared it a pandemic, which, according to DrTedro Adhanom Ghebreyesus, the wHO director-general, "is not just a public health crisis; it is a crisis that will touch every sector. So, every sector and every individual must be involved in the fight." ${ }^{\prime 5}$ P HEIC is defined in the wHO's Inter-

\footnotetext{
53 https://citizen.co.za/news/covid-19/2320oo1/why-alcohol-sales-are-banned-again-read -ramaphosas-full-speech/.

54 Ukah, "Sacred Surplus and Pentecostal Too-Muchness," 333.

55 The "status" of the disease, whether the coronavirus is an "object," a chance occurrence, revenge of nature, or an instrument of divine wrath is still a matter of debate and arguments, see Raoni Wohnrath Arroyo, "Is Coronavirus an Object? Metaphysics meets Medical Sciences," Voluntas: Revista International de Filosofia 11, no. 7 (2020) 1-8.

$5^{6}$ https://www.who.int/westernpacific/emergencies/covid-19.
} 
national Health Regulations as 1) "an extraordinary event which is determined ... to constitute a public health risk to other States through the international spread of disease; [and] 2) to potentially require a coordinated international response. ${ }^{57}$ Declaring CoviD-19 a pandemic means the disease is a global outbreak or spread of a deadly disease..$^{58}$

We have never before seen a pandemic sparked by a coronavirus. This is the first pandemic caused by a coronavirus ... Pandemic is not a word to use lightly or carelessly. It is a word that, if misused, can cause unreasonable fear, or unjustified acceptance that the fight is over, leading to unnecessary suffering and death. ${ }^{59}$

Epidemics and pandemics are demographic catastrophes that interrogate a society's deeply held assumptions about the meaning, value, and purpose of human life and community. Because of the epidemiological, social, and moral attributes of pandemics, they produce or occasion "new rules of existence."60 Furthermore, they challenge and present a crisis of faith for religious communities, especially about the power and benevolence of the deity.

Christianity, however, is not underequipped historically or culturally for dealing with demographic catastrophes; the Christian past is a reservoir of resources for dealing with pandemics. It is often forgotten that Christianity was born in the crucibles of turmoil, social-political turbulence, disasters, epidemics, plagues, and diseases. As historians of the early church record, in $165 \mathrm{CE}$ an epidemic of massive proportions - sometimes called the Antonine Plague

57 WHO, International Health Regulations, 2nd ed. (Geneva: WHO, 2005), 9. Since defining the PHEIC in 2005, the concept has been applied six times: in 2009 to describe the "swine flu," in 2014 to describe polio, in 2014 concerning Ebola, in 2016 concerning the Zika virus, and again in 2019 to describe Ebola and in 2020 to describe the coronavirus.

58 The word "pandemic" comes from the Greek $\pi \hat{\alpha} \nu=$ pan $=$ "all" and $\delta \hat{\eta} \mu \circ \varsigma=$ demos = "people." See K. David Patterson, "The Influenza Pandemic of 1918-1919 in the Gold Coast", The Journal of African History 24, no. 2 (1983): 485-502. The epidemiological attributes of a pandemic include high mortality, high disease mobility, panic causing, the absence of preventive and curative treatment or drugs, and contagion. Its moral attributes include fear, blame, moral uncertainty, and extreme emergency measures and a state of exceptions. See David Casciano, "CoviD-19. Discipline and Blame: From Italy with a Call for Alternative Futures," Journal of Extreme Anthropology 4, no. 1 (2020): E18-E24.

59 wHo director-general Dr. Tedro Adhanom Ghebreyesus, Media address on March 21, 1020, https://www.who.int/dg/speeches/detail/who-director-general-s-opening-remarks-at -the-media-briefing-on-covid-19---11-march-2020.

6o Pierluigi Consorti, "Religion and Virus," in Pierluigi Consorti, ed., Law, Religion and covid19 Emergency (Pisa: DiReSom, 2020), 15. 
or the Plague of Galen (165-180CE) — swept through the Roman Empire for fifteen years, decimating "a quarter to a third of the empire's population"61 and causing "significant population decreases in Egyptian cities." ${ }^{2}$ Again, in $251 \mathrm{CE}$, another lethal epidemic (the Plague of Cyprian [251-266]), ${ }^{63}$ ravaged the empire, significantly depopulating both rural areas and cities within the empire. According to Rodney Stark, "had some crises [such as plagues and epidemics] not occurred, the Christians would have been deprived of major, possible crucial opportunities" to establish their credibility, maintain and build new networks and make more conversions to their rank. ${ }^{64}$ While civil constructions were halted in the aftermaths of the epidemics, the building of sacred sites and ceremonial ways intensified as "[Emperor] Marcus Aurelius [161-180] invested heavily in restoring the temples and shrines of Roman deities,"65 perhaps to propitiate the gods for mercy and stem the tide of Christian conversions as Christians were observed to have responded to the epidemic with care for the sick. How a religious community responds to the challenges of demographic catastrophes is important in materializing belief in action and in establishing its credibility.

In the African worldview, religion, disease and healing and health are intimately intertwined. A key concern and objective of religious involvement in this cosmology are the provision and maintenance of health and the management of existential vulnerability. ${ }^{66}$ This concern partly explains why and how African Christians of all shades crave for religion-mediated healing. The history of ancient African Christianity elaborately describes how early African Christians (for example, Tertullian of Carthage, Cyprian of Carthage, and Dionysius of Alexandria) responded to epidemics of the second and third centuries of the Common Era. ${ }^{67}$ While epidemics have no religion or ethnicity or nationality or skin pigmentation, as the COVID-19 has so far convincingly demonstrated,

61 Rodney Stark, The Rise of Christianity: How the Obscure, Marginal Jesus Movement became the Dominant Religious Force in the Western World in a Few Centuries (New York: HarperSanFrancisco, 1997), 73 .

62 Sarah K. Yeomans, "Classical Corner: The Antonine Plague and the Spread of Christianity," Biblical Archaeology Review 43, no. 2 (2017): 22.

63 The plague is named after Bishop Thaschus Cæcillus Cyprianus of Carthage (ca. 200$258 \mathrm{CE}$ ), who provided a rich and elaborate account of the epidemic in his Pastoral Letter, Mortality, written ca. 250 CE. See: St. Cyprian, Treatises, trans. and ed. Roy J. Deferrari (Washington DC: Catholic University of America Press, 1958), 195-224.

64 Stark, The Rise of Christianity, 74; quotation from p. 93. Emphasis in original.

65 Sarah K. Yeomans, "Classical Corner," 24.

66 Ukah, "Religion in Pre-Contact Africa," 47-61.

67 David E. Wilhite, Ancient African Christianity:An Introduction to a Unique Context and Tradition (New York: Routledge, 2017), 108-169. 
there may, perhaps, be discernible and distinctive perspectives to epidemics according to Christian history, doctrines, and practices. Rodney Stark claims that during the plagues of the second and third centuries, "the contents of Christian and pagan beliefs were different in ways that greatly determined not only their explanatory capacities but also their relative capacities to mobilize human resources." ${ }^{\prime 68}$ Stark's reasoning is consistent with the action and teaching of Martin Luther during the bubonic plague that struck the city of Wittenberg in August 1527. Luther's daughter was killed during this period, but he did not flee the city in fear for his life. Luther and his wife, Katharina, stayed behind in the city to take care of the infected, turning their home into a space for the treatment of the sick. Under the condition of the plague, Luther went on to write a tract in which he articulates a reasoned and theological response to the question "Whether One May Flee from a Deadly Plague."69 According to Luther, no one should dare leave his neighbor unless others will take care of the sick in their stead and nurse them. He admonishes his readers to respect the word of Jesus Christ,

"I was sick and you did not visit me ..." [Matt. 25:41-46]. According to this passage, we are bound to each other in such a way that no one may forsake the other in his distress but is obliged to assist and help him as he himself would like to be helped. ${ }^{70}$

In addition to the long Christian history and experience with calamities and epidemics, the African past and present hold important resources for the continent's Christians in dealing with pandemics. Existential and ontological insecurity, risk, and uncertainty could be said to be a default situation in Africa, where socioeconomic indicators usually point downward and individuals provide for their needs rather than depend on the state to provide municipal resources. ${ }^{71}$ In the recent past, however, Africa and Africans faced a situation

68 Stark, The Rise of Christianity, 79.

69 Martin Luther, "Whether One May Flee from a Deadly Plague” (1527), in Luther's Works 43, Devotional Writings II, ed. Jaroslav Jan Pelikan, Hilton C. Oswald, and Helmut T. Lehmann (Philadelphia: Fortress Press, 1999), 119-138.

$70 \quad$ Luther, "Whether One May Flee from a Deadly Plague," 120.

71 According to the International Labour Organisation, about 66 percent of employment in sub-Saharan Africa and $5^{2}$ percent in North Africa is in the informal sector. The informalization of the African economy will increase even more in the context of the COVID-19 pandemic, considering job losses across sectors and the heightened inability of African states to cope with the burdens of the pandemic and international debts. See: World Economic Forum, "Africa is Creating One World's Largest Single Markets. What 
similar to (if not worse than!) the ongoing CoviD-19 pandemic. Between 1918 and 1919, the influenza pandemic, sometimes called the Spanish flu because it was first detected in Spain, ravaged large swaths of the African continent. According to M. Heaton and T. Falola, the pandemic was of "unprecedented virulence" and within a year was "ultimately responsible for somewhere between 30,000,000 and 50,000,000 deaths worldwide. ${ }^{72}$ Africa lost a greater percentage of its population to that pandemic than did Europe; although "[e]ach continent lost roughly 2.3 million lives to the influenza [...] Africa suffered far more disproportionately from the influenza pandemic." ${ }^{73}$ As Howard Phillips further confirms, "Of all six continents, Africa — and particularly sub-Saharan Africasuffered the highest average mortality rate in the pandemic." ${ }^{74}$ The African experience and interpretation of the pandemic also differed from how it was experienced elsewhere in the world. The local interpretations were mostly political, economic, and religious. Many African churches and communities, such as the Aladura churches in West Africa ${ }^{75}$ and spiritual churches in eastern and southern Africa, ${ }^{76}$ were established in the wake of the crisis to respond to the challenges the pandemic posed. Africans are used to dealing with life's and nature's existential precariousness and both historical precedents and religiocultural institutions were mobilized to do this. While CoviD-19 may present mixed opportunities for African religious communities, the context and circumstances are different, and so are the principal social actors. Arguably, the pentecostal community in Africa is placed in a unique situation to innovate under Covid-19 conditions.

The pentecostal community, with its ritual and doctrinal emphases on physiological healing, the power of the Holy Spirit, and the use of spiritual gifts, and its modernist outlook, is adequately positioned to respond in innovative ways to the COVID-19 pandemic. Pentecostal communities in Africa are bet-

Does This Mean for Entrepreneurs?," https://www.weforum.org/agenda/2019/o5/AfCFTA -africa-continental-free-trade-area-entrepreneur/ (accessed July 12, 2020).

72 M. Heaton and T. Falola, "Global Explanations versus Local Interpretations: The Historiography of the Influenza Pandemic of 1918-1919 in Africa," History in Africa 33 (2006): 205.

73 Heaton and Falola, "Global Explanations versus Local Interpretations," 214.

74 Howard Phillips, "Influenza Pandemic (Africa)," in 1914-1918 Online International Encyclopedia of the First World War, Dor: 10.15463/ie1418.10431.

75 J.D.Y. Peel, Christianity, Islam, and Orișa: Three Traditions in Comparison and Interaction (Berkeley: University of California Press, 2016), 79, 232; also, Aladura: A Religious Movement among the Yoruba (Oxford: Oxford University Press, 1968); Robert Cameron Mitchell, "Religious Change and Modernization: The Aladura Churches among the Yoruba in Southwestern Nigeria," PhD diss., Northwestern University, Everton, Illinois.

76 Howard Phillips, "Why Did It Happen? Religious and Lay Explanations of the Spanish Flu Epidemic of 1918 in South Africa," Kronos 12 (1987): 72-92. 
ter equipped in terms of strategic organizational structures and practices than some other religious organizations. The African Initiated (Independent/Instituted/Indigenous) Churches (AICs) are less embedded in the media and own satellite television stations to broadcast their programs, as numerous pentecostal organizations are routinely accustomed to. ${ }^{77}$ Pentecostal churches are already embedded in media and commercial communication networks with a strong social media presence. Many of these organizations own and operate satellite radio and television broadcasting networks that reach millions of followers across continents. Facebook, Twitter, Instagram, and YouTube are familiar turfs for pentecostal self-representation; many of these megachurches have developed their own dedicated social media apps, such as Christ Embassy's Kingschat App $^{78}$ and the Redeemed Christian Church of God's "mobile products" (apps that require paid-for activation PIN s). ${ }^{79}$ They also have sophisticated websites with online stores and electronic payment capabilities. Already, they have long years of practice in how to optimally use and manipulate these technologies to promote and market their personalities, shows, religious goods, and wares. It is very easy, therefore, for them to migrate their services to online platforms. ${ }^{80}$ Some pentecostal churches own banks and other financial facilities that they have been using for several years to avoid being tracked and monitored by the state. Under emergency and state-imposed and -enforced social distancing rules, these structures will now be repurposed toward online religious services and collection of resources. For pentecostal churches whose leaders and owners are already media megastars, and unlike the AIC s or even some mainline churches such as Catholic parishes, for example, congregational worship and activities were not as much as shuttered as migrated and redeployed on cyberspace, creating "the distanced church." ${ }^{81}$ Churches are now instructing their members on how to download banking

77 Stephen Victor Coertze, "Challenges Facing the African Church: South African Theologians Speak Out," MA diss., Department of Science of Religion and Mission, Faculty of Theology, University of Pretoria (2005).

78 https://christembassy.org/loveworld-apps/.

79 https://www.rccg.org/rccg-mobile-products/.

8o Asonzeh Ukah, "Wundermanagement-Gesetz, Autorität und Regulierung religiösen Rundfunks in Nigeria," in Bernt Schnettler, Thorsten Szydlik, and Helen Pach, eds., Religiöse Kommunikation und weltanschauliches Wissen: Kommunikative Konstruktionen unabweisbarer Gewissheiten und ihre gesellschaftlichen Wirkungen (Wiesbaden: Springer Fachmedien, 2020), 81-101; Ogbu Kalu, "The Big Man of the Big God: Popular Culture, Media, and the Marketability of Religion,"New Theology Review: An American CatholicJournal for Ministry 20, no. 2 (May 2007): 15-26.

81 Heidi A. Campbell, ed., The Distanced Church: Reflections on Doing Church Online (2020). Available electronically from http://hdl.handle.net /1969.1/187891. 
apps to facilitate electronic fund transfer to churches' accounts. Controversial South African-based Malawian pentecostal entrepreneur Prophet Shepherd Huxley Bushiri, founder-owner of Enlightened Christian Gathering Church, set up subscription-only online religious services where worshipers pay the sum of 80 Rands monthly to gain access. ${ }^{82}$ Unarguably, in the context of remote working under physical and social distancing because of the CoviD-19 pandemic, the Pentecostals have a comparative advantage over other religious organizations with little experience with the media, especially the Internet. Pentecostalism seems to have been preparing for exactly such a situation as the CoviD-19 pandemic brought about (without knowing it, even though prophesying about the future events is another staple of African pentecostal offering ${ }^{83}$ ).

Does misfortune come to a city

If Yahweh has not caused it?

Amos 3:6

In contemporary Africa, the most pronounced reactions to the pandemic, after those from official government actions mandating and enforcing lockdowns across many African countries, have been religious. There is a variety of religion-related responses to the COVID-19 pandemic, which is not surprising considering the "famed notoriety" of African religiosity, which is evident in perspectives and in mobilizing human action. ${ }^{84}$ Religious responses have come to the forefront of explanation, analysis, and responses to CoviD-19 because Africans seek an understanding and interpretations of the "why" of the pan-

82 Botho Molosankwe, "Shepherd Bushiri Launches Online Church Only Accessible to Subscribers," https://www.iol.co.za/the-star/news/shepherd-bushiri-launches-online-church -only-accessible-to-subscribers-46929879 (accessed July 12, 2020). On Bushiri's biography and some of the many controversies his practices have engendered in South Africa, see Ilana van Wyk, "Crooked Prophets, Ungodly Politicians and their Publics," 36-48.

83 Ukah, "Sacred Surplus," 336-337; "Prophecy, Miracle and Tragedy: The Afterlife of T.B. Joshua and the Nigerian State," in Pieter Coertzen, M. Christian Green, and Len Hansen, eds., Religious Freedom and Religious Pluralism in Africa: Prospects and Limitations (Stellenbosch: sun PReSS, 2016), 209-232.

84 Asonzeh Ukah, "The Deregulation of Piety in the Context of Neoliberal Globalization: African Pentecostalisms in the Twenty-First Century," in Vinson Synan, J. Kwabena Asamoah-Gyadu, and Amos Yong, eds., Global Renewal Christianity: Spirit-Empowered Movements Past, Present, and Future, vol. 3: Africa (Lake Mary, FL: Charisma House, 2016), 362-378. 
demic. African religious leaders, both Christian and Muslim, have, therefore, been offering various interpretations of the virus and its patterns of mobility and ultimate purpose. ${ }^{85}$ Pentecostal leaders in many African societies are consistent in their outlook that the CoviD-19 has a religious meaning, purpose, and objective. Mapping out some of these reactions is important in understanding the place and overarching role of Pentecostalism as a meaning-making system and a structure of urban livelihoods. Part of the importance of the pentecostal explanations on the "why" of the pandemic stems from the selfpresentation and claims of these leaders to know the mind of God in a fresh apocalyptic moment of insights about end-times and "the coronavirus plague," as Helen Ukpabio described it. ${ }^{86}$ Some of the information, sermons, messages, and interpretations circulating from church leaders indicate different perceptions, perspectives, and practices regarding how churches and their leaders are coping with and adapting to the new and unusual circumstances of coviD19. Interpreted as a plague, the COVID-19 pandemic is seen as understandable and controllable as divine retribution ${ }^{87}$ that prescribes a course of action as a remedy: return to God, prayers, acknowledgement of God in human affairs, and so forth. ${ }^{88}$ Some claim that the pandemic is not caused by a virus but is

85 Across sub-Saharan Africa, the response to the state-informed lockdown and social distancing rules from mainline churches, Episcopal conferences, Catholic Bishops Conferences, as well as from imams and ulamas "shows in general, an attitude of collaboration, adherence and support to government directives, often supported by practical indications that interpret them in a restrictive and prudential sense," Stefano Picciaredda "Religions, Africa and Covid-19," in Pierluigi Consorti, ed., Law, Religion and Covid-19 Emergency, $109-118$ at 111 .

86 Helen Ukpabio, “Corona Virus Plague Reveals God's Anger," https://www.facebook.com/ ladyapostlehelenukpabio/videos/533021300734044/ (the sermon was preached on Sunday February 23, 2020).

87 The notion that COVID-19 is a plague sent by God to devastate humanity for its shortcomings implies that God is vengeful and vindictive. More important, it indicates that God uses the force of physical punishment to change the self-chosen destiny of a people or humanity, and therefore makes free will and freedom a mockery. Such a notion further challenges the idea, unique to Christianity, that God loves humanity (John 3:16; 1 Cor 1:2). These notions about God's violent judgment against humankind, as attractive as they may seem to a variety of persons such as Helen Ukpabio, are open to contestation and debate from sociological, historical, and theological and scriptural perspectives. However, they reflect aspects of both the Old and New Testaments that describe scenes of gruesome cosmic battles, apocalyptic plagues, and bloodshed as instruments of divine wrath and messengers. See John J. Collins, "The Bible and the Legitimation of Violence," Reflections 91, no. 1 (Winter 2004): 1-7; Shelly Matthews and E. Leigh Gibson, eds., Violence in the New Testament (New York: T \& T Clark, 2005). 
a byproduct of $5 \mathrm{G}$ telecommunications technology. ${ }^{89}$ The unfolding scenario will undoubtedly influence many of the outcomes that government-instituted social and medical or financial measures will produce. If, for example, the COVID-19 pandemic is interpreted either as a cleansing plague sent by God or a tactic of Satan and bioweapon engineered by members of the Illuminati who control Western capital and technology, ${ }^{90}$ the invisible-to-the-naked eye virus assumes a religious personality and status as a divine messenger executing a sacred and spiritual function. It will further mystify the origin of the disease and accentuate the mysteriousness of the entanglements of the natural and biocultural consequences of the pandemic. ${ }^{91}$ Further, some pentecostal leaders have claimed that the pandemic is a harbinger of the "end-time," a prelude to the second coming of Jesus Christ. Pentecostals have been preaching this message of end-time as a stable and staple doctrine for several decades now. Consistent with this doctrine, the pandemic, therefore, could be a time to put into practice the demands and norms that such a doctrine necessitates. Consequently, the COVID-19 pandemic is the perfect storm for African pentecostal leaders and the labyrinthine networks and empires they have built over the decades to demonstrate their "relative capacities to mobilize human resources." ${ }^{2}$

Lagos, Nigeria, is generally regarded as the pentecostal capital of the world on account of the strong presence of megachurches and the crowds they pull together each week. The social, physical, and economic presence of Pentecostalism in the city is ubiquitous. Furthermore, "Nigeria holds the world record in terms of time and money devoted to prayers and religious activities."93 Nigerian pastors serve as mentors, standard-bearers, and sources of inspiration

89 Chris Oyakhilome, founder-owner of Christ Embassy Church and LoveWorld Television Network, was sanctioned by the United Kingdom's Office of Communications (Ofcom) for broadcasting information deemed "injurious" and "harmful" to its "well over 50 million faithful adherents" "about the coronavirus, alleging links to ${ }_{5} \mathrm{G}$ technology," Ofcom Broadcast and On Demand Bulletin 402 (May 18, 202O), 3, 10.

$90 \quad$ Ofcom Broadcast and On Demand Bulletin, 13.

91 In Iran, South Korea, the United States of America, Hong Kong, and Singapore, religious communities have been actively implicated in the mass transmission of covid-19. In many African countries - for example, in Nigeria, Zimbabwe, Uganda, and Kenya - some pentecostal pastors and their congregations have either been dispersed by force by the police or their leaders arrested for breaking lockdown and self-isolation rules. In South Africa, a Christian church has been identified as a super-spreader of the virus as it held religious events in which many attendees afterward tested positive for CoviD-19.

92 Stark, The Rise of Christianity, 79.

93 Jibrin Ibrahim, "Covid-19 and the Age of Precarity," Premium Times (Abuja), April 10, 2020, https://opinion.premiumtimesng.com/2020/04/10/covid-19-and-the-age-of-precar ity-by-jibrin-ibrahim/. 
to other pastors elsewhere in Africa. In the context of the raging Covid-19, Nigerian pentecostal pastors have proved to be ambivalent in their responses and actions. Shutting down schools and all religious centres and activities that hold more than fifty persons in Lagos on March 20, 2020 triggered anger and defiance rather than compliance and support among pentecostal pastors. ${ }^{94}$ David Oyedepo, the founder-owner of the Living Faith Church franchise, was the first to flout the shut-down forty-eight hours later by holding a Sunday service even when police officers showed up to advise against it. In response, Oyedepo claimed that "[s] hutting down churches would be like shutting down hospitals. There are many, many places that would never have any medical solution but in church ... ${ }^{95}$ It is not a number of people that makes [sic] fellowship, it is the gathering of the brethren." 96

Many smaller and medium-sized churches complied with the ban on highdensity gathering, forcing the public to ask what is special about Oyedepo and the Winners Chapel franchise. The public and social media outcry against Oyedepo's flagrant disregard of the government instruction compelled him to issue a letter of apology through his special assistant, Steve Ogah, in which he rationalized his action thus:

[A]s a responsible organization, Living Faith Church fully supports and encourages compliance with all initiatives of [the] government to combat the spread of this dreaded virus. However, information has to be strategically disseminated to the grassroot[s], noting that the Church is a family and not an industry, it is a most effective reason that enlightenment and sensitization from the Church platform is a most effective way to get peo-

94 https://dailypost.ng/2020/o3/20/covid-19-panic-tension-as-coronavirus-spreads-across -nigerian-as-churches-schools-public-institutions-shut-down/.

95 Oyedepo makes a correct assertion that there are many places in Nigeria (and Africa by extension) that do not have a medical facility, that are healthcare deserts, and that churches are the next best thing to a healing facility. However, African pentecostal organizations such as Oyedepo's Winner's Chapel, the Redeemed Christian Church of God, Mountain of Fire and Miracles, and similar spiritual franchises have failed to build and operate healthcare facilities that would benefit the poor at no cost and bring quality health care closer to this cohort of marginalized people. When pentecostal organizations establish and manage healthcare and educational facilities, they operate them on a for-profit basis, thereby catering only to the needs of the rich in the society and perpetuating the exclusion and neglect of the poor.

96 Samuel Ogundipe, "Coronavirus: Oyedepo Holds Service, Vows to Keep Winners Chapel Open," Premium Times (Lagos), March 23, 2020, https://www.premiumtimesng.com/news /headlines/383340-coronavirus-oyedepo-holds-service-vows-to-keep-winners-chapel-op en.html. 
ple involved in playing their part in terms of prayers and intercessions and not just staying away from Church without knowing what to do.... As a responsible and law-abiding organization, we wish to state that we will ensure compliance with government directives in all our churches across the state. ${ }^{97}$

The Redeemed Christian Church of God (RCCG) is the largest pentecostal franchise in Africa. On account of its size, wealth, long history, and self-definition as a successful spiritual-economic corporation, many other pentecostal churches see it as a trendsetter and a paradigm of power and copy its theology, rituals, and practices. ${ }^{98}$ Enoch Adeboye, the leader of the RCCG, like Helen Ukpabio, claimed that CoviD-19 is God's manifestation of his power especially among technologically advanced nations that pride themselves for their medical advances in tackling human problems. Because the pandemic is God performing his awesome power before nations, the virus will not come close to those "who serve God wholeheartedly" —as if viruses discriminate based on piety. In a short, thirty-two-second video released on his Twitter handle (@PastorEAAdeboye), Adeboye said:

I want to assure you that there's no virus that'll come near you at all because it is written that he who dwells in the secret place of the most high shall abide under the shadows of the almighty. I believe that this is a time for God to show you that there's a difference between those who serve him wholeheartedly and those who do not. It shall be well with you. You'll have peace and good health. ${ }^{99}$

Since thousands of Christians have died from the coviD-19 pandemic, a ready interpretation from the perspective of Adeboye would be that those who died from the COVID-19 infection were not serving God wholeheartedly. Many Christians would also believe that since they have been serving God wholeheartedly, they are automatically immune from the virus. "Serving God wholeheartedly," according to Adeboye's definition, includes principally paying one's tithes (!).

\footnotetext{
97 "Oyedepo Begs Ogun State Govt for Flouting Ban on Large Gathering," Premium Times (Lagos), March 24, 2020, https://www.pmnewsnigeria.com/2020/o3/24/oyedepo-begs -ogun-govt-for-flouting-ban-on-large-gathering/.

98 Asonzeh Ukah, A New Paradigm of Pentecostal Power: The Redeemed Christian Church of God in Nigeria (Lawrenceville, NJ: Africa World Press, 2008), 173.

99 Stephen Charles Kenechukwu, "Adeboye: Coronavirus Won't Come Near You If You Serve God," The Cable Lifestyle (Lagos), https://lifestyle.thecable.ng/adeboye-coronavirus-wont -come-near-you-if-you-serve-god/.
} 
Although Adeboye urged people to follow the best government instruction and medical advice, such as social distancing and frequent washing of hands, it is easy to see how pentecostal interpretations of the pandemic could give rise to problematic social outcomes and accelerate the spread and lethality of the virus. Perhaps to assuage public controversy stoked by his early comment, the RCCG patriarch donated several medical supplies to the Lagos State government, including 200,000 hand gloves, 8, ooo bottles of hand sanitizer, and 8,ooo surgical face masks. Also, the church donated eleven Intensive Care Units (ICUs), beds fully fitted with ventilators in Lagos, Ogun, and Plateau States to contribute to the improvement of healthcare facilities in Nigeria. Similarly, Oyedepo's Winners Chapel announced the donation of ambulances, test kits, and personal protective devices (PPES) to the Lagos and Ogun State governments. ${ }^{100}$ Because religious organizations have been ambivalent about the pandemic and resistance has come mainly from religious leaders and their followers, president Muhammadu Buhari targeted this sector in this speech on April 13 extending the lockdown in Lagos and Ogun states and Abuja for a further two weeks: "This [CoviD-19] is not a joke. It is a matter of life and death. Mosques in Makkah and Madina have been closed. The Pope celebrated [Easter] Mass on an empty St. Peter's Square. The famous Notre Dame cathedral in Paris held Easter Mass with less than 10 people ... We cannot be lax."101 In other words, Buhari told Nigerians that they cannot be more Christian than the pope and Parisians or be more Muslim than the Saudis.

\section{6} Conclusion

Pentecostalism in Africa has grown from small storefront congregations to multi-congregational megachurches and franchises with multi-billion dollars' net worth and strong media, social, economic, and political presence in many African cities. The relevance of these organizations has been debated for many years. This essay has examined two principal aspects of African pentecostal self-assessment in relation to the African condition; these aspects, broadly regarded as the pentecostal economy of healing, are socioeconomic change

\footnotetext{
100 https://www.vanguardngr.com/2020/04/covid-19-adeboye-oyedepo-donate-medical-sup plies-to-lagos-ogun/; https://www.bbc.com/news/world-africa-52189785. What is intriguing is not that these megachurches donated medical items to state governments but how they were able to purchase these items while state governments and medical agencies were unable to procure them.

101 https://businessday.ng/lead-story/article/buhari-extends-lockdown-by-two-weeks/.
} 
and the rhetoric of physiological healing in the context of the CoviD-19 pandemic. For one thing, Pentecostalism has achieved a formidable numerical strength, but its practices, revolving as they do around "pentecostal big men and women" and doctrines about individual salvation, profit, and benefit, have an inverse relationship with the socioeconomic well-being of Africans. ${ }^{102}$ Pentecostal entrepreneurs have become stupendously wealthy by extracting resources from many sources and concentrating these in a few hands, mainly their own and those of their immediate family members and collaborators. Commonly generated and owned wealth has not trickled down to church members or the larger society. For another, major pentecostal actors have failed to respond collectively to COVID-19 with the hindsight of the resources and history of Christianity's encounter with epidemics, pandemics, and other demographic catastrophes. In the wake of COVID-19 in Africa in 2020, Pentecostalism has the perfect opportunity to demonstrate its theological and doctrinal refinement and articulation relative to this unprecedented demographic tragedy. Pentecostal organizations also have the context to motivate practical human action in response to the uncertain and existential precariousness that the pandemic is provoking. These leaders who have in the past built their reputation and religio-economic capital on grandiose claims about making people rich and wealthy, healing and prophecy have not made any remarkable impact on addressing the lasting consequences of the CoviD-19 pandemic. While some Pentecostals are aligning their message and actions in support of government activities and medical-scientific advice and also providing scarce materials and supplies for frontline healthcare workers, many are focused on extracting resources from suffering church members. What seems to be missing in the pentecostal responses to CoviD-19 is a reasoned, reassuring, and courageous, even empathic voice about the pandemic that is consistent with the long history and resources of Christian leaders dealing with similar catastrophes. Because many Africans trust their religious leaders more than their politicians, the confusing and ambivalent responses from pentecostal leaders may cause more harm than good in both the short and long terms.

That a virus is capable of shutting down the massive monthly gathering of the RCCG, or causes the proud and arrogant David Oyedepo, who claims to have prophetic power and anointing above political leaders, to apologize and cower in silence, or reveals the hubris of T.B. Joshua's or Emmanuel Makandiwa's (of Zimbabwe) ${ }^{103}$ claimed prophetic anointing to be demonstrably and incontrovertible off the mark is a lesson in itself for the pentecostal community.

102 Kalu, "The Big Man of the Big God," 15-26.

103 Emmanuel Makandiwa of United Family International Church claimed to have foreseen 
For scholars of African Pentecostalism, there is also a lesson in how to assess the self-assured success and (economic/political) power of Pentecostalism in Africa. Covid-19 has shown that there are no "pentecostal republics" in Africa. The answer to Africa's problem of marginality can hardly be found in religion, least of all in Pentecostalism as currently produced, branded, circulated, and consumed. Consistent with, and informed by, the precepts of the legal-economic methodology, the institutions, organizational structures, and resources of African Pentecostalism are informed and driven by the economic welfare of its leaders rather than by the common good. During a public health crisis, it takes the decisive power and infrastructure of the postcolonial state to demonstrate where public trust and capital lie. According to Thucydides, life during the Peloponnesian war between Athens and Sparta between 431 and 405 BCE was anomic. People became indifferent to religion and law because large numbers of people were "dying indiscriminately." 104 COVID-19 could as much lay bare where the real power and resources of Africa and Africans lie: in religion or the political economy of the postcolonial state. So far, the covid-19 pandemic has shown that political, state, and governance institutions are the repository of real transformative power to alter the fate of Africa and the overall well-being of its citizens.

the pandemic in a prophecy that he announced to his congregation in Harare in 2015, 2016, and 2017. He called the virus a "demonic spirit on [a] rampage." The question is, what is the value of his prophecy if the world first knows about it now after CoviD-19 has claimed half a million lives? Like much of T.B. Joshua's alleged prophecy, what is the value, socially and theologically, of so-called prophecies after the fact? See: http://www.ufiministries.org/ update-emmanuel-makandiwas-coronavirus-covid-19-prophecy-summary-of-events/; https://www.youtube.com/watch?v=7Gfn_GiZRF8.

104 Thucydides, History of the Peloponnesian War, rev. ed., trans. Rex Warner, ed. M.L. Finley (London: Penguin Classics, 1972), 53. 